\title{
Why Use Music in English Language Learning? A Survey of the Literature
}

\author{
Dwayne Engh ${ }^{1}$ \\ ${ }^{1}$ English Teacher, Tudor BEC College London, U.K. \\ (Received Masters in English Language Teaching and Applied Linguistics, King's College London, 2010) \\ Correspondece: Dwayne Engh, St. Peter's Vicarage, 53 Belsize Square, London, U.K. NW3 4HY. E-mail: \\ dwayneengh@shaw.ca
}

$\begin{aligned} & \text { Received: December 9, } 2012 \quad \text { Accepted: December 22, } 2012 \quad \text { Online Published: January 9, } 2013 \\ & \text { doi:10.5539/elt.v6n2p113 URL: http://dx.doi.org/10.5539/elt.v6n2p113 }\end{aligned}$

\begin{abstract}
The use of music and song in the English language-learning classroom is not new. While many teachers intuitively feel that music is beneficial in teaching English language, there is sometimes a lack of the theoretical underpinnings that support such a choice. There are examples in the literature to argue the strong relationship between music and language that are substantiated by research in the fields of cognitive science, anthropology, sociolinguistics, psycholinguistics, First Language Acquisition (FLA) and Second Language Acquisition (SLA).
\end{abstract}

Keywords: music, song, English language learning

\section{Introduction}

The use of music and song in the English language-learning classroom is not new. As early as Bartle (1962), Richards (1969) or Jolly (1975), scholars have been arguing for use of music in a language acquisition context for both its linguistic benefits and for the motivational interest it generates in language learners.

There are examples in the literature to argue the strong relationship between music and language that are substantiated by research in the fields of cognitive science, anthropology, sociolinguistics, psycholinguistics, First Language Acquisition (FLA) and Second Language Acquisition (SLA). Music had been used on occasion with the Audiolingual Method in language teaching classrooms to reduce the boredom that could occur from repetitive drills from the 1950s through to the 1970s (Bartle, 1962; Kanel, 2000) and later, the use of classical instrumental music was used with the goal to produce a relaxed state of mind that makes the brain receptive to inputs and activates the subconscious in Suggestopedia methodology (Lozanov, 1978; see also Bancroft, 1978). However, it may not have been until Communicative Language Teaching (CLT) and Task Based Learning (TBL) approaches became more pervasive that there was a sudden demand for pedagogical material for the use of songs in the language-learning classroom (Griffee, 2010).

\subsection{Why is it Important?}

There were two important outcomes from the author's recent research (2010) into effective use of music in the English language classroom (in press). One suggested that there was strong support for use of music in the language-learning classroom, but that there was actually very little occurring in most classrooms. Connected, but a separate issue, implied that while many teachers intuitively felt music was beneficial in teaching English language, there was also the perception that there was a lack of understanding of the theoretical underpinnings that supported such a choice. Therefore, some educators felt unable to defend the decision to champion use of music in the classroom to administrators, business English students or those in a predominantly exam focused environment.

Salcedo (2010), after a survey of foreign language teaching journals, suggests there are "only a few articles on the subject compared to multitudinous articles on other methodological ideas". Other scholars have noted this as well: Coe (1972) stated there have been no controlled music use in the language classroom experiments and Griffee (1989), in an editorial introduction discussing why songs and music aren't used more extensively in the language classroom, suggests there exists a lack of theoretical perspective and empirically based research in the field. I would propose that, while there has been some progress in this subfield, little has changed throughout the past decades. 


\subsection{Subsections of Literature Review}

In this literature review, I will examine academic perspectives from within the field of applied linguistics and will make connections to the field from other disciplines that argue there is a firm empirical, theoretical and pedagogical basis to consider for the use of music as an aid in language acquisition. The examination of the literature will consider the following five categories:

1. Sociological Considerations

2. Cognitive Science

3. First Language Acquisition

4. Second Language Acquisition

5. Practical Pedagogical Resources

\section{Sociological Considerations}

There are four distinct sections in the exploration of Sociological Considerations that will be discussed. Those include the areas of Anthropological Arguments, Community, Breaking Boundaries and Culture.

\subsection{Anthropological Arguments}

The connection of song to both the development of human languages and the linguistic development of the individual are anthropologically worth noting (Murphey, 1990). Livingstone (1973), in a contentious article that made extrapolations from physical anthropological research of birdsong and mammal behaviour, hypothesised that humans evolved song before speech. While this can never conclusively be proven (see Count, Hewes, Livingstone \& Mourant, 1974 for counter-argument), it raises interesting connections to infant development and first language acquisition research that will be discussed later in this review. From a social anthropological perspective, Merriam (1964) has argued that the survival of literature, epic poetry and ballads in oral traditions must be credited to the use of song. The odes of praise and stories of the tribe were passed on through song so that the texts would not be forgotten before the written word developed. Rubin (1995) suggests this may be because of the multilayered patterns of rhythm, sound, linguistic meaning and emotional content functioning simultaneously. Lastly, drawing on anthropological and ethnomusicological literature, Trehub and Trainor (1998) examine the historical and cultural functions of songs in child care, claiming "the descriptive evidence seems to suggest that the practice of singing to infants and many details of song form and style are rooted in ancient traditions that have survived industrialization and urbanization" (43). It does appear the anthropological development of human languages is, to some extent, connected to music and song.

\subsection{Community}

In addition to being utilized by caregivers and individual storytellers in oral traditions, singing has also historically evolved as a collective activity. It is communally practiced by people not requiring professional training, with a wide range of experience levels, and in a variety of settings including leisure, religious or educational communities. It is argued that use of song in the language classroom enhances social harmony (Huy Le, 1999), creates a safe space to experience learning collectively and contributes to the building of a community (Lems, 1996; Lake, 2003); all of which are essential factors for effectively attaining teaching and learning goals. Specifically examining trust and cooperation, Anshel and Kipper (1988) suggest that group participation in singing positively influences both trust and cooperation, which are primary contributors to the progression of group cohesion and a sense of community (see McMillan \& Chavis, 1986 for further discussion of theories of community). Gao (2008), while discussing use of karaoke and singing contests as evidence of learner collaboration in English Corners in China, approaches the humanistic learning that can occur within this type of community as following traditional Chinese cultural values and Confucian pedagogical traditions (see also Nguyen, Terlouw \& Pilot, 2006). The literature appears to suggest that the specific feeling of belonging to a cohesive community, that many teachers explicitly strive to establish for their learners in the classroom, can be promoted by use of music and collective singing.

\subsection{Breaking Boundaries}

Music consistently surrounds our lives and may potentially assist educators in removing boundaries between the various communities that students belong to (Nagy \& Herman, 1987). Extending their work, Medina (1990) suggests it may be beneficial to attempt methods that more closely resemble life outside of the institutional classroom, which is generally filled with music, songs, stories and visual images. Because students learn a great deal of language before school age and outside of the institution once school has begun, it is potentially justifiable to consider non-traditional teaching methods that are less structured and ritualised. 
Cheung (2001) prefers the image of music bridging gaps between 'formal and informal' learning as opposed to breaking boundaries and Huy Le (1999) extends this bridging of formal and informal learning environments to include the bridging of the gap between teachers and students as well. By breaking down the boundaries or bridging the gaps between stereotypical 'institutional' learning and the 'informal' learning of our homes, work places and school grounds, we can continue to engage students in natural and authentic language that they will want to practice independently out of class (Jenkins \& Dixon, 1983; Harwood, 1998). In a study of young learner's engagement in music beyond the institutional classroom, Campbell (1998) discusses how the function of music in learner's lives, the use of music in play and the manner of musical enculturation relate to the place of music in institutional educational settings, suggesting more music should occur in educational institutions supporting Murphey's (1992a) argument that the school environment is the only place in society not using music and song to its full potential.

\subsection{Culture}

Candlin, in the preface as series editor that Songs in Action (Griffee, 1992) was a part of, argues for the importance songs may provide as an historical and social cultural context to the language being acquired. He states:

To be sure, songs have a place in the classroom for helping create that friendly and co-operative atmosphere so important for language learning, but they can offer much more. They offer insights into the culture and especially the stories and myths of different societies, providing a window into the frames of reference and values of the peoples whose language we are learning. (Candlin, 1992: ix)

There are two areas to consider under the heading of culture. First, that Pop Culture is a global phenomenon orientated toward a common youth culture with pop songs as its backbone (Griffee, 1992) and hence is something that is both significant and familiar to the students (Dubin, 1975). Therefore, use of music from Pop Culture allows a window to the target language of 'their culture' (Cheung, 2001; Plagwitz, 2006) and not only works to bridge the gap between generations, between pre-defined teacher-student roles and between the stereotypical formal and informal learning environments, but also validates and empowers 'their music', 'their language' and 'their culture' (Hamblin, 1987; Domoney \& Harris, 1993).

Secondly, songs are a potentially culturally rich resource for the language classroom (Murphey, 1992b; Ajibade \& Ndububa, 2008) that can explicitly be used to teach the cultural norms and ideals of the target language (Gravenall, 1945; Jolly, 1975). Music, while universal, is culturally specific in that the musical content and style mirror a particular culture, acting as a cultural artefact that may both reflect and influence that culture (Griffee, 1992; Failoni, 1993; Mishan, 2005). "The introduction of vocal music as the foundation on which to either build a coordinated language-culture course or, more often, supplement an already established program, can be a powerful tool, especially when the music is a faithful reflection of the culture from which it derives" (Jones, 2008: 10). While a number of academics agree and appear to support the pedagogical use of music to increase cultural competency in the culture of the target language (i.e. Saricoban \& Metin, 2000; Orlova, 2003), there are other linguists such as Huy Le (1999) who argues "that music, particularly songs, is an encoding of cultural values and ideology which needs to be viewed critically if foreign music is used in teaching a second language..." The use of music in the classroom raises significant questions concerning how culture, language and identity are related, and therefore demands critical reflective thought, if not a level of caution regarding the potential linguistic and cultural imperialism that could occur (see Pennycook 2003, 2007 for further discussion of transcultural flows and performativity with relationship to culture and identity).

We now move from the discussion of Sociological Considerations into the exploration of the cognitive and neural relationship of language and music.

\section{Cognitive Science}

Cognitive research investigates the anatomic structure of the brain and its neural functions, suggesting that language and music have important points of convergence and/or overlap. There are multiple recent studies in this field, likely somewhat due to the increase in sophistication of neuroscience technology as well as increased interest from within the field in the neural and functional structure of both language and music domains (for developmental comparison, see McMullen \& Saffran, 2004). Additionally, the popularisation of some studies such as the 'Mozart Effect' (Rauscher, Shaw \& Ky 1993, 1995; Hetland, 2000) by Campbell (1997) has brought increased attention from the general public to the field of cognitive science. The original Rauscher et al. (1993, 1995) study extended the work of French therapist Tomatis (Thompson \& Andrews, 2000) and indicated an enhancement of spatial-temporal abilities after listening to music composed by Mozart, an assertion that has been disputed by Chabris (1999), Nantais and Schellenberg (1999), Steele, Bass and Crook (1999) and Steele et 


\section{al. (1999).}

Cognitive science research agrees that there are important connections between music and language:

Like language, music is a human universal involving perceptually discrete elements organized into hierarchically structured sequences. Music and language can thus serve as foils for each other in the study of brain mechanisms underlying complex sound processing, and comparative research can provide novel insights into the functional and neural architecture of both domains. (Patel, 2003: 674)

There is, however, an interesting contradiction noted in the literature debating how that occurs. The evidence from neuropsychology argues that musical and linguistic elements can be dissociated, and therefore may work together as discrete domains. Borchgrevink (1982) postulated that linguistic and musical elements are processed in different hemispheres of the brain and therefore language and music used concurrently provides effective pedagogical methodology to increase learning, while Jackendoff $(1991,2006)$ describes how music parallels the perception of language and suggests a 'parallel architecture' approach. It is argued that language and music collaborate but operate in different domains, so that "from a conceptual standpoint, music and language must be dissociated, or else there would be no possibility for cooperation" (Steinke, Cuddy \& Holden, 1997: 316). A specific study of song lyrics and melody processing suggest "that the monitoring of speech and music in songs is performed by independent neural processors" (Peretz, 2002: 174) and a research study of how phonemes and pitch are controlled in different but collaborating areas corroborate those findings that the two aspects of language "are handled separately, yet in harmony by a musical-linguistic collaboration" (Zatorre, Meyer, Gjedde \& Evans, 1996: 848).

Yet these conclusions stand in direct contrast to recent neuroimaging data, which indicates a convergence in the processing of the syntactic relations in language and music (Patel, 2003). This suggests that musical structure is processed in language areas of the brain (Patel, Edward, Ratner, Besson \& Holcomb, 1998; Koelsch, Gunter \& Friederici, 2000; Koelsch et al., 2002), specifically "localized in Broca's area and its right-hemisphere homologue, in areas involved in syntactic analysis during auditory language comprehension... indicating that these regions process syntactic information that is less language-specific than previously believed" (Maess, Koelsch, Gunter \& Friederici, 2001: 540; also see Levitin \& Menon, 2003). Hence, because they are processed in the same region, our brains may recognise aspects of linguistic and musical sequences in a similar manner.

Patel (2003) and Slevc, Rosenberg and Patel (2008) suggest a possible resolution to this contradiction in the literature with the use of linguistic and musical syntactic processing cognitive theories, postulating "a specific point of convergence between these theories leads to the hypothesis that syntax in language and music share a common set of processes (instantiated in front brain areas) that operate on different structural representations (in posterior brain areas)" (Patel, 2003: 674).

As we move from the area of Cognitive Science to that of First Language Acquisition, Gomez and Gerken (2000) act as a transition in their literature review of cognitive research discussing the possible contributions and correlations of the language acquisition device (LAD) and associative learning functions through the methodology of testing artificial language learning and language acquisition in infants. The studies reviewed raise significant questions with respect to whether such neural functions are general or specific to language. "The fine-grained characterizations of infant learning mechanisms that this approach permits should result in a better understanding of the relative contributions of, and the dynamic between, innate and learned factors in language acquisition" (ibid: 178).

\section{First Language Acquisition}

The FLA field offers a number of insights that corroborate the arguments of Cognitive Neuroscience for the innate connection of language and music in human beings. Loewy (1995) postulates that music acts as the prelinguistic carrier for communicative intent, essentially that a foundation for peer social interaction is built through the infant's preverbal communication of crying. Other scholars, such as Chen-Hafteck (1997), suggest that the prelinguistic phase discussed in FLA literature is similar to the premusical phase discussed by musicologists, which echoes arguments that song-like vocalisation will commonly precede language in regular ontogenetic development (Murphey, 1989).

Music and language are the two ways that humans communicate and express themselves through sound. Since birth, babies start to listen and produce sound without distinguishing between music and language, singing and speech. (Chen-Hafteck, 1997: 85)

The intentional experimentation with linguistic production occurs through prosodic elements of speech and the vocal contour, including manipulating tone, timbre, stress and rhythm in the infant's 'indistinct babbling' 
vocalisation that precedes specific linguistic and musical production. "This music of speech is the earliest dimension of language that is used and understood by children" (Loewy, 1995: 61). Papousek and Papousek $(1981,1991)$ support Loewy's proposition and argue there is very little difference between spoken intonational contour and sung melodic contour before the first lexical items are acquired by infants, which is corroborated by empirical research (Trehub, Trainor \& Unyk, 1993) that tracked language development in infants by analysing pitch contours in linguistic and musical material.

It is argued the input infants receive in affective 'baby-talk' or infant-directed speech prosody (Trainor, Austin \& Desjardins, 2000), as well as the songs mothers and other caregivers sing (Bergeson \& Trehub, 2002), has an impact of linguistic and musical development. Nursery rhymes and lullabies are some of the first language input that occurs with enough repetition to encourage memorization and therefore acquisition (Howle, 1989). Murphey and Alber (1985) note that as children grow up, they receive less and less of the affective musical 'motherese' language that caregivers use with infants and postulate it is replaced by pop music as the "motherese of adolescents', as well as suggest connections between the motherese of adolescents and the benefits of 'affective foreigner talk' (see also Murphey, 1992a). This affective foreigner talk is observed in language teachers as a simplified code of comprehensible input at the appropriate language level in the language-learning classroom, noting that the use of modified intonation is often instinctive from both language teachers and caregivers, who are often unaware that they are 'singing' with an exaggerated pronunciation and hyperbolic melodic contour at that moment (Fonseca Mora, 2000). It appears that melodic musicality of speech is not only significant to FLA, but to the entire language acquisition process and connections can be drawn between first language and second language acquisition literature as we move into the next section.

\section{Second Language Acquisition}

For the purposes of this literature review, the extensive field of SLA research as it applies to use of music in language-learning will be discussed under the headings: Affective Filters, Motivation, Learning Strategies and Empirical SLA Studies.

\subsection{Affective Filters}

The 'affective filter hypothesis' (Krashen, 1982) argues that the most favourable learning occurs in a setting of low anxiety, self-confidence and high motivation. Built on SLA research, the hypothesis states "acquirers with a low affective filter seek and receive more input, interact with confidence, and are more receptive to the input they receive" (Richards \& Rodgers, 2008: 183). An exploration of the literature regarding how affective filters may relate to the use of music and song in the language classroom (Merriam, 1964; Coe, 1972; Claerr \& Gargan, 1984; Wilcox, 1995) suggests that music lowers affective barriers and assists in making students more relaxed, thereby more receptive to language learning. Based on corpus analysis, pop songs are conversation-like, repetitive and occur at roughly half the speed of spoken discourse (Murphey, 1992b), therefore also lowering affective barriers. "This simplicity, their highly affective and dialogic features, and their vague references (ghost discourse), allow listeners to use them in personally associative ways" (Murphey, 1992b: 771). Connecting this argument to earlier "motherese of adolescents" discussions, it is postulated pop songs create a low affective filter and Murphey characterises them as a 'teddy-bear-in-the-ear' because of their riskless nature. Additional research examining differences in affective filter, stress levels and language acquisition (Ganschow et al, 1994) implies the anomie language-learners feel, which may include a sense of homelessness, social uncertainty and dissatisfaction, can be addressed by use of music in the classroom (Schoepp, 2001; Lake, 2003).

\subsection{Motivation}

Motivation is multifaceted and concerns both the affective states and attitudes that impact the amount of effort a learner expends to acquire a new language. The degrees of the various types of instrumental, integrative, resultative and intrinsic motivation (Ellis, 1997) differ with the individual student and the literature supports the use of song and linguistic play in the language classroom (Cook, 1997) to increase individual language-learner motivation (see also Ndububa \& Ajibade, 2006; King, 2010).

The validity of using authentic and natural language input "including real-world/target tasks, pedagogical tasks and enabling skills" (Nunan, 2004: 19) so that "there is some sort of relationship to comparable real-world activities" (Skehan, 1998: 95) has been noted as a motivating factor in the language classroom (see also Nunan, 1989; Bell \& Gower, 1998; McGrath, 2002). Mishan (2005) contends that because music is an authentic activity that occurs among first language users both in terms of discussion of popular music as well as in the group singing that occurs at many public events ranging from karaoke to football, it also proves motivating to use for language-learners in a classroom setting (see also Cook, 1997). The arguments that the rhythmic patterns of 'Jazz Chant' are fragments of authentic language use (Graham, 1992); that popular rock music provides meaningful 
authentic activity with frequent integrated exposure (Domoney \& Harris, 1993); that rock songs are short, accessible authentic texts rich in content that work as a catalyst to engage with and build meaning from (Pope, 1995); that the poetry of rock music provides a valid authentic text (Abrate, 1983; Griffee, 1992); and that this 'rock poetry' may be considered an example of inclusive literature (Ferradas Moi, 1994, 2003), all provide further support to the motivating factor of music in the language classroom.

\subsection{Learning Strategies}

It has been suggested that motivation may have connections to other individual learner differences in second language acquisition such as learner strategies, learner autonomy and preferred learning styles (Sinclair, 1996; Cohen, 1998; Benson, 2006). Separating potential interconnectivity of the variables between motivations, individual learning preferences due to multiple intelligences and learner strategies (Carrell, Pharis \& Liberto, 1989; Brown, 2007) therefore becomes an issue. There is also a strong possibility that the influence of learning environments, which may include family, educational and cultural background factors might have an effect on the learner (Locastro, 1994; Harley, 2000). Gardner (1999) acknowledges Locastro's point when considering the impact of personal decisions in the expression of multiple intelligences (Chen \& Gardner, 2005) and defines intelligence as "a biopsychological potential to process information that can be activated in a cultural setting to solve problems or create products that are of value in a culture" (Gardner, 1999: 33). Fonseca Mora (2000) applies Gardner's multiple intelligences hypothesis specifically to language teaching (see also Berman, 1998) and asserts "one of the main implications for teaching of this theory was that students should not only be taught to increase their verbal, spatial, and numerical intelligences, but also to nurture their musical, bodily-kinaesthetic, interpersonal, and intrapersonal intelligences" (146).

Although there are, admittedly, some challenges with the learner strategy literature in general, there are a number of researchers who remain enthusiastic about the value of language learner strategies (Oxford, 1990; Naiman, Frohlich, Stern \& Todesco, 1996; Chamot, 2005), suggesting that a more genuine interaction occurs (Lam \& Wong, 2000). When music is situated as an aid to learning strategies in the language classroom, both cognitive and metacognitive strategies are enhanced (Jones, 2008), affective exploration is increased (Cullen, 1998) and the student is more receptive to language inputs (Bancroft, 1978; Lozanov, 1978; Magahay-Johnson, 1984).

This leads us now to specific empirical research regarding the use of music and its effect on second language acquisition.

\subsection{Empirical SLA Studies}

There is ample empirical evidence to suggest that use of music and song enhances students' success in second language acquisition, which will be discussed in three sections: Recall and Memory, The Din/Involuntary Mental Rehearsal and Language Specific Skills. Medina claims "the conclusions for the use of music in the second language classroom are clear. Since music can be as viable a vehicle for second language acquisition as stories, then songs should not be treated as extra-curricular entities" (1990: 18).

\subsubsection{Recall and Memory}

Empirical research comparing conventional pedagogical methods with those that use music and song has produced positive results in the area of vocabulary recall. For example, studies with primary students by Medina (1990) investigated effectiveness of vocabulary acquisition with the use of music and story illustrations, and a study by Schunk (1999) examined the effect of signing when coupled with singing on receptive vocabulary skills.

Based on research using background music to aid verbal phrase recall, Fonseca Mora (2000) asserts that songs have a positive outcome on the students' language acquisition and that lexical patterns stored in long-term musical memory can be retrieved with ease at a later date for mental rehearsal, memorisation or during oral interaction. Wilcox (1995) studied the pronunciation of target vocabulary in adult learners through use of music cues to aid prosodic memory, which is confirmed by research into vocabulary recall attached to visual or auditory cues (Brown \& Perry, 1991), and research into music-dependent memory using background musical cues with specific target vocabulary (Balch, Bowman \& Mohler, 1992). Brutten, Angelis and Perkins (1985) explored this research further by testing oral proficiency using musical ability and memory in English language learners and suggested that innate musical abilities and verbal memory may have accounted for score variances.

Pop songs are useful for not only discrete lexical vocabulary item recall, but also for longer utterances and formulaic phrases. For example, Wray and Perkins (2000) have suggested that most speech is the repetition and variation of memorized formulas, and that these formulaic lexical phrases are flexible and therefore allow for many repetitions. Distinctive intonation, rhythmic and stress patterns can accompany each formulaic unit when 
incorporating the multiple formulaic lexical phrases found in songs, making it easier for the learner to remember and apply.

The use of rhythm and rhyme to assist auditory recall has also been studied, and the multimodal combination of rhythm, melody and rhyme along with linguistic prosody appears to lead to greater retention (Graham, 1992; Palmer \& Kelly, 1992). This has been applied to language learning in a study of rhyming ability of preschool children as a phonological skill (Bryant, MacLean, Bradley \& Crossland, 1990) and applied to English verse (Kelly \& Rubin, 1988), where connections are suggested between children's verse and acquisition of prosodic rules (see also Krumhansl, 2000 for further psycholinguistic research in this area).

\subsubsection{The Din / Involuntary Mental Rehearsal}

Murphey (1989) provides potential evidence regarding why music effectively assists in lexical and phrasal recall in noting the resemblance of songs to conversational discourse and suggests they are linguistically processed in a similar manner. "Thus, song may be called pseudo-dialogal or a form of Piaget's (1923) egocentric language, a form of egocentric language that at first may be pronounced for us but is soon appropriated by us, psychologically and subvocally if not actually sung aloud" (Murphey, 1989: 168). He subsequently goes on to hypothesize a relationship between Piaget's (1923) egocentric speech, Krashen's (1983) involuntary verbal rehearsal, Vygotsky's (1934) inner speech and postulates the 'song-stuck-in-my-head' (SSIMH) phenomena. "The similarity of the Din to the SSIMH phenomenon is suggested... It is hypothesized that song may act as a LAD activator, or be a strategy of the LAD in the ontogenetic development of language" (Murphey, 1990: 53). The argument for subvocal involuntary mental rehearsal is corroborated as potential evidence why songs in the language classroom have such a positive effect on delayed vocabulary, formulaic lexical phrases and extended text recall (Fonseca Mora, 2000; Salcedo, 2010).

\subsubsection{Language Specific Skills}

SLA research has also examined specific language skills that can be effectively developed with the use of music and song, such as explicit development of listening discrimination and comprehension. This has been examined for improving aural comprehension and spelling through use of modified cloze procedure (Froehlich, 1985); in a comparative study of conventional listening exercises and pop song gap-fill exercises (Kanel, 1997); through the use of music with passage correction tests (Odlin, 1986); and as practice for extracting meaning from noise with the 'mondegreens' found in pop music (Smith, 2003). Music in the language classroom may also be utilized with an explicit vocabulary and grammar focus (Richards, 1969; Saricoban \& Metin, 2000) and used to reinforce either grammar or pronunciation points (Allen \& Vallette, 1977). Pronunciation and phonology are a natural use of songs in the aid of second language acquisition (Schön et al, 2008), and Leith (1979) states:

...there is probably not a better nor quicker way to teach phonetics than with songs. Phonetics instruction is one good use to which songs can be put even in beginning classes (540).

The repetitive nature of songs makes them effective use for pronunciation drills (Bartle, 1962; Techmeier, 1969; Shaw, 1970) and lastly, it is argued that songs contextually introduce supra-segmental features (Lems, 2001; Wong and Perrachione, 2006), which aids in the learning of patterns for word identification.

\section{Practical Pedagogical Resources}

In the examination of the academic literature, we have seen a strong empirical and theoretical basis for the potential music has as an aid to language acquisition. However, there appears to be a dearth of current literature that discusses the extent to which teachers are using music and the manner in which it is being used in a practical context. Of the little research exploring teacher attitudes and practice that does exist, it seems to focus on primary school age children and rarely discusses the use of music and song with teen or adult learners. In the last category of the literature review, a brief survey, which does not claim to be exhaustive, of recent textbook publications and website journal articles may give some indication as to how music is being applied and what principles are being recommended in this representative sample.

There are a number of web resources for use of music in the language classroom, including examples of practical lesson discussions with theoretical support in online journals such as the Internet TESL Journal or Humanising Language Teaching Magazine. Examples include the use of music while writing to develop critical thinking (Aloha, 2005); use of music in language play (Cakir, 1999; Saricoban \& Metin, 2000); use of music in conversation classes (Orlova, 2003); and use of song lyric 'word clouds' as corpora for the language classroom (Kryszewska, 2010). There are also quite a few examples of downloadable lessons and worksheets from various websites, the majority of which focus on grammatical or vocabulary activities, but few, if any, include any rationale or theoretical basis for decisions made in the development of the materials. 
Of the teacher resource books published since 2000, there is a focus on young learners, such as the Paterson and Willis (2008) 'English Through Music' from the Oxford basics for children series, which includes 36 varied practical activities with a theoretical discussion of rationale for music use, what opportunities there are for language learning and improving the musical quality of classroom singing. There are also approaches that replace the original words of familiar folk, pop or children's song melodies in order to learn phonics and grammatical concepts. For example, the melody of Frère Jacques is used with different words so that it becomes Talking and Walking, with a focus on the spelling rules of long vowels and silent vowels in the 'Sing Your Way Through the Phonics' program (Gifford, 2000); Rock Talk (Redding, 2006) explores basic grammar and phonics through rock melodies; and, in an effort to learn phonics and grammatical rules, the 'Learning English Through Songs' and 'Phonics the Fun Way' programs (Gabriel, 2007, 2010) use familiar children's songs such as Twinkle, Twinkle Little Star and replaces the words to become the Grammar Rules' Song or a song to learn Prepositions with Rhyming Words using structure 'There are...'. There are also products that specialise in writing songs explicitly for the language learning market such as the Tutortunes 'grammatically focused pop' Top-40-style song, Next to Me (Lock, 2009), which includes 54 different prepositions, or the Days of the Week (Mol, 2008) from Supasongs, presumably both modelled to some degree on earlier language and music resources such as the grammar-orientated Hard to Learn that English as a Second Language Blues (Wellman \& Byrd, 1975).

There were a number of resource books about music use in the language classroom published in 1992 or immediately after, including Graham (1992), who created the concept of 'Jazz Chants', the rhythmic unison speaking of chants and poetry in the language classroom. Cranmer and Laroy (1992), Griffee (1992) and Murphey (1992) were also all published in the same year as part of different publisher's established resource book series. Central to the Cranmer and Laroy (1992) text, which focuses on the use of Western orchestral music, is the technique of inner eye visualization, of the "ability to form images in the mind in response to a musical stimulus" (ibid: 2). The Griffee (1992) text also explores the affective response to music in a variety of approaches from dictations to listening exercises to music surveys and a number of extension activities along with firm theoretical underpinning to the choices made, noting that "songs create their own world of feeling and emotion, and as we participate in the song, we participate in the world it creates" (ibid: 4). Lastly, Murphey's (1992) text explores music and video, learner autonomy and a variety of authentic language activities that occur in first language discourse. Although first published in 1976, Grenough (1994) later republished and includes sheet music, lyrics, worksheet questions and visuals with additional information. If continuously published and therefore current in its song choices, it could prove to be a valuable resource, but by naming and working with specific pop songs, the text has a dated feel that the Griffee and Murphey texts do not. Unfortunately, out of all the texts mentioned in the last paragraph, Music and Song (Murphey, 1992) is the only one still in print at this time, which clearly limits the options for language teachers wanting to use music in the classroom.

\section{Conclusion}

One is left with a number of questions based on the literature review of theoretical, empirical and practical classroom resources just completed. If connections between music and language are as strong as the literature reviewed above suggests, why is there such disparity between theoretical support and practical application in the classroom? Why, outside of a few young learner texts, has there been such a gap in teacher pedagogical resource books supporting the use of music in language learning since the early 1990s? Why are the needs of adult and teen learners not reflected in the current web or print pedagogical resources?

\subsection{Further Research}

Given the limitations of the author's original study, there appears to be a need for additional research of a similar nature examining teacher attitudes and practices with a larger sample size in order to increase statistical significance. Furthermore, several interesting questions arising from the study point to a need for further research. There is a need for an in-depth study with a class of teen and adult learners to measure effects of a music intensive teaching methodology versus conventional methodologies. There is also a need to establish, by conducting research on subjects of various age levels, whether the influence of music is greater at any one particular developmental period. Additionally, further exploration of teacher attitudes and prejudices pertaining to Hip-Hop and rap, making connections to World Englishes and identity, is in order. Lastly, little has been done in the subvocal involuntary mental rehearsal of the Song-Stuck-In-My-Head-Phenomenon (Murphey, 1990) and the motherese of adolescence (Murphey \& Alber, 1985; Murphey, 1992a) since first published, although "both are still viable concepts and researchable" (Murphey, 2010).

\subsection{Pedagogical Implications}

A number of practical suggestions made by respondents during the course of the author's study point to ways 
that a possible disconnect between teacher theoretical support and classroom use can be bridged. Numerous respondents requested materials development as a resource for use of music by language teachers. Of the many useful music books aimed at English language teachers of adult and teen students published in the 1990s, only the Murphey (1992) is still available. Therefore, the suggestion from many respondents to publish new materials may be valid. Potential suggestions include (1) a journal aimed specifically at uses of music in language teaching, with opportunity for feedback and conferences (2); a practical resource book with ready-made photocopiable lesson plans and worksheets (3); and lastly, an edited collection of music in language-learning journal articles so that teachers and future researchers can easily access the growing body of published research in this subfield. This literature review is an attempt to address the last point.

\subsection{Closing}

Overall, the results are clear in suggesting use of music and song in the language-learning classroom is both supported theoretically by practicing teachers and grounded in the empirical literature as a benefit to increase linguistic, sociocultural and communicative competencies. From an educational standpoint, music and language not only can, but should be studied together.

\section{References}

Abrate, J. (1983). Pedagogical Applications of the French Popular Song in the Foreign Language Classroom. The Modern Language Journal, 67(1), 8-12. http://dx.doi.org/10.2307/326687

Ahola, S. (2005). Digger Deeper into Songs: A Writing Activity. The Internet TESL Journal, XI(2). Retrieved 20.12.2012 from http://iteslj.org/Lessons/Ahola-Songs.html

Ajibade, Y., \& Ndububa, K. (2008). Effects of Word Games, Culturally Relevant Songs, and Stories on Students' Motivation in a Nigerian English Language Class. TESL Canada Journal/Revue TESL du Canada, 25(2), 27-48.

Allen, J., \& Vallette, E. (1977). Classroom teaching of foreign languages and English as a second language. Chicago: University of Chicago Press.

Anshel, A., \& Kipper, D. (1988). The Influence of Group Singing on Trust and Cooperation. Journal of Music Therapy, 25(3), 145-155.

Balch, W., Bowman, K., \& Mohler, L. (1992). Music-dependent memory in immediate and delayed word recall. Memory \& Cognition, 20(1), 21-28. http://dx.doi.org/10.3758/BF03208250

Bancroft, W. (1978). The Lozanov Method and Its American Adaptations. The Modern Language Journal, 62(4), 167-175. http://dx.doi.org/10.2307/324351

Bartle, G. (1962). Music in the language classroom. Canadian Modern Language Review, Fall, 11-14.

Bell, J., \& Gower, R. (1998). Writing course materials for the world: a great compromise. In Tomlinson, B. (ed.), Materials Development in Language Teaching (pp. 116-129). Cambridge: Cambridge University Press.

Benson, P. (2006). Autonomy in language teaching and learning. Language Teacher, 40, 21-40. http://dx.doi.org/10.1017/S0261444806003958

Bergeson, T., \& Trehub, S. (2002). Absolute Pitch and Tempo in Mothers' Songs to Infants. Psychological Science, 13(1), 72-75. http://dx.doi.org/10.1111/1467-9280.00413

Berman, M. (1998). A Multiple Intelligences Road to an ELT Classroom. Wales: Crown House Publishing Limited.

Borchgrevink, H. (1982). Prosody and musical rhythm are controlled by the speech hemisphere. In Clyne, M. (ed.), Music, Mind, and Brain: The Neuropsychology of Music (pp. 151-157). New York: Plenum.

Brown, H. (2007). Principles of Language Learning and Teaching (5 $5^{\text {th }}$ edition) (pp. 132-151). New York: Pearson.

Brown, T., \& Perry, F. Jr. (1991). A Comparison of Three Learning Strategies for ESL Vocabulary Acquisition. TESOL Quarterly, 25(4), 655-670. http://dx.doi.org/10.2307/3587081

Brutten, S., Angelis, P., \& Perkins, K. (1985). Music and Memory: Predictors for Attained ESL Oral Proficiency. Language Learning, 35(2), 299-313. http://dx.doi.org/10.1111/j.1467-1770.1985.tb01030.x

Bryant, P., MacLean, M., Bradley, L., \& Crossland, J. (1990). Rhyme and Alliteration, Phoneme Detection, and $\begin{array}{llll}\text { Learning to Read. Developmental } & \text { Psychology, }\end{array}$ http://dx.doi.org/10.1037//0012-1649.26.3.429 
Cakir, A. (1999). Musical Activities for Young Learners of EFL. The Internet TESL Journal, V(11). Retrieved 20.12.2012 from http://iteslj.org/Lessons/Cakir-MusicalActivities.html

Campbell, D. (1997). The Mozart Effect: Tapping the Power of Music to Heal the Body, Strengthen the Mind, and Unlock the Creative Spirit. New York: Avon Books Inc.

Campbell, P. (1998). The musical cultures of children. Research Studies in Music Education, 11, 42-51. http://dx.doi.org/10.1177/1321103X9801100105

Candlin, C. (1992). Preface in Griffee, D. Songs in Action: Classroom Techniques and Resources (ix-x). New York: Prentice Hall.

Carrell, P., Pharis, B., \& Liberto, J. (1989). Metacognitive Strategy Training for ESL Reading. TESOL Quarterly, 23(4), 647-678. http://dx.doi.org/10.2307/3587536

Chabris, C. (1999). Prelude or requiem for the 'Mozart effect'? Nature, 400, 826-827.

Chamot, A. (2005). Language Learning Strategy Instruction: Current Issues and Research. Annual Review of Applied Linguistics, 25, 112-130. http://dx.doi.org/10.1017/S0267190505000061

Chen, J., \& Gardner, H. (2005). Assessment Based on Multiple-Intelligences Theory. In Flanagan, D., \& P. Harrison (eds.), Contemporary Intellectual Assessment: theories, tests, and issues (pp. 77-102). New York: Guilford Press.

Chen-Hafteck, L. (1997). Music and language development in early childhood: Integrating past research in the two domains. ECDC, 130, 85-97. http://dx.doi.org/10.1080/0300443971300109

Cheung, C. K. (2001). The use of popular culture as a stimulus to motivate secondary students' English learning in Hong Kong. ELT Journal, 55(1), 55-61. http://dx.doi.org/10.1093/elt/55.1.55

Claerr, T., \& Gargan, R. (1984). The Role of Songs in the Foreign Language Classroom. OMLTA Journal, FL014904, 28-32.

Coe, N. (1972). What use are songs in FL teaching? International Review of Applied Linguistics in Language Teaching, 10(4), 357-360.

Cohen, A. (1998). Strategies in learning and using a second language. London: Longman.

Cook, G. (1997). Language Learning, Language Play. ELT Journal, 51(3), 224-231. http://dx.doi.org/10.1093/elt/51.3.224

Count, E., Hewes, G., Livingstone, F., \& Mourant, A. (1974). On the Phylogenesis of the Speech Function. Current Anthropology, 15(1), 81-90. http://dx.doi.org/10.1086/201440

Cranmer, D., \& Laroy, C. (1992). Musical Openings: Using music in the language classroom. Essex: Addison Wesley Longman Limited.

Cullen, B. (1998). Music and Song in Discussion. The Internet TESL Journal, IV(10). Retrieved 20.12.2012 from http://iteslj.org/Techniques/Cullen-Music.html

Domoney, L., \& Harris, S. (1993). Justified and Ancient - Pop Music in EFL Classrooms. ELT Journal, 47(3), 234-241. http://dx.doi.org/10.1093/elt/47.3.234

Dubin, F. (1975). An Overlooked Resource for English Language Teaching: Pop, Rock, and Folk Music. CATESOL (California Association of Teachers of English to Speakers of Other Languages) Occasional Papers, No. 2, ED126673.

Ellis, R. (1997). Second Language Acquisition: Oxford Introductions to Language Study. Oxford: Oxford University Press.

Failoni, J. (1993). Music as Means to Enhance Cultural Awareness and Literacy in the Foreign Language Classroom. Mid-Atlantic Journal of Foreign Language Pedagogy, 1, 97-108.

Ferradas Moi, C. (1994). Rock poetry: the literature our students listen to. The Journal of the Imagination in Language Learning, 2, 56-9. Jersey City State College.

Ferradas Moi, C. (2003). Materials for Language through Literature. Rocking the Classroom: Rock Poetry Materials in the EFL Class'. In Tomlinson, B. (ed.), Developing Materials for Language Teaching (pp. 406-421). London: Continuum.

Fonseca Mora, C. (2000). Foreign language acquisition and melody singing. ELT Journal, 54(2), 146-152. http://dx.doi.org/10.1093/elt/54.2.146 
Froehlich, J. (1985). Improving Aural Comprehension and Spelling through a Modified Cloze Procedure Using Songs and Poems. Die Unterrichtspraxis/Teaching German, 18(1), 49-54. http://dx.doi.org/10.2307/3529993

Gabriel, B. (2007). Learning English Through Songs. Singapore: Bettyland Publications.

Gabriel, B. (2010). Phonics the Fun Way. Singapore: Bettyland Publications.

Ganschow, L., Sparks, R., Anderson, R., Javorshy, J., Skinner, S., \& Patton, J. (1994). Differences in Language Performance among High-, Average-, and Low-Anxious College Foreign Language Learners. The Modern Language Journal, 78(1), 41-55. http://dx.doi.org/10.2307/329251

Gao, X. (2008). English Corner as Out of Class Learning. ELT Journal, 63(1), 60-67. http://dx.doi.org/10.1093/elt/ccn013

Gardner, H. (1999). Intelligence reframed. New York. Basic Books.

Gifford, M. (2000). Sing Your Way Through Phonics: Song Lyrics (Volumes I, II, III). Beavercreek: Action Factor Publishing.

Gomez, R., \& Gerken, L. (2000). Infant artificial language learning and language acquisition. Trends in Cognitive Sciences, 4(5), 178-186. http://dx.doi.org/10.1016/S1364-6613(00)01467-4

Graham, C. (1992). Singing, Chanting, Telling Tales: Arts in the Language Classroom. New Jersey: Prentice Halls.

Gravenall, B. (1945). Music in Language-Teaching. ELT Journal, 3(5), 123-127. http://dx.doi.org/10.1093/elt/III.5.123

Grenough, M. (1994). Sing It! Learn English Through Song Text/Workbook(Vol. 2). Mexico: McGraw-Hill, Inc.

Grenough, M. (1994). Sing It! Learn English Through Song Text/Workbook(Vol. 5). Mexico: McGraw-Hill, Inc.

Griffee, D. (1989). Editorial Introduction. The Language Teacher, XIII(5), 3.

Griffee, D. (1992). Songs in Action: Classroom Techniques and Resources (ix-x). New York: Prentice Hall.

Griffee, D. (2010). Personal communication with the author.

Hamblin, V. (1987). Integrating Popular Songs into the Curriculum. The French Review, 60(4), 479-484.

Harley, B. (2000). Learning Strategies in ESL: Do Age and L1 Make a Difference. TESOL Quarterly, 34(4), 769-777.

Harwood, E. (1998). Music Learning in Context: A Playground Tale. Research Studies in Music Education, 11, 52-60. http://dx.doi.org/10.1177/1321103X9801100106

Hetland, L. (2000). Listening to Music Enhances Spatial-Temporal Reasoning: Evidence for the "Mozart Effect". Journal of Aesthetic Education, 34(3, 4), 105-148. http://dx.doi.org/10.2307/3333640

Howle, M. (1989). Twinkle, twinkle little star: It's more than just a nursery song. Children Today, 18(4), 18-22.

Huy Le, M. (1999). The Role of Music in Second Language Learning: A Vietnamese Perspective. Paper presented at Combined 1999 Conference of the Australian Association for Research in Education and the New Zealand Association for Research in Education: LE99034.

Jackendoff, R. (1991). Musical Parsing and Musical Affect. Music Perception, 9(2), 199-229. http://dx.doi.org/10.2307/40285529

Jackendoff, R. (2006). A Parallel Architecture perspective on language processing. Brain Research, 1146, 2-22. http://dx.doi.org/10.1016/j.brainres.2006.08.111

Jenkins, J., \& Dixon, R. (1983). Vocabulary Learning. Contemporary Educational Psychology, 8, 237-260. http://dx.doi.org/10.1016/0361-476X(83)90016-4

Jolly, Y. (1975). The Use of Songs in Teaching Foreign Languages. The Modern Language Journal, 59(1,2), 11-14. http://dx.doi.org/10.2307/325440

Jones, R. (2008). Echoing Their Lives: Teaching Russian Language and Culture Through the Music of Vladimir S. Vysotsky. Dissertation, University of Texas at Austin.

Kanel, K. (1997). Teaching with Music: A comparison of conventional listening exercises with pop song gap-fill exercises. JALT Journal, 19(2), 217-234. 
Kanel, K. (2000). Songs in Language Teaching: Theory and Practice. Paper presented at The Proceedings of the JALT (Japan Association for Language Teaching) $25^{\text {th }}$ Annual International Conference on Language Teaching \& Learning and Educational Materials Expo, 69-75.

Kelly, M., \& Rubin, D. (1988). Natural Rhythmic Patterns in English Verse: Evidence from Child Counting-Out Rhymes. Journal of Memory and Language, 27, 718-740. http://dx.doi.org/10.1016/0749-596X(88)90017-4

King, R. (2010). Music and Storytelling in the EFL Classroom. Humanising Language Teaching, 12(2). ISSN 1755-9715. Retrieved 20.12.2012 from http://www.hltmag.co.uk/apr10/sart05.htm

Koelsch, S., Gunter, T., \& Friederici, A. (2000). Brain Indices of Music Processing: "Nonmusicians" are Musical. Journal of Cognitive Neuroscience, 12(3), 520-541. http://dx.doi.org/10.1162/089892900562183

Koelsch, S., Gunter, T., Cramon, D., Zysset, S., Lohmann, G., \& Friederici, A. (2002). Bach Speaks: A Cortical "Language-Network" Serves the Processing of Music. NeuroImage, 17, 956-966. http://dx.doi.org/10.1006/nimg.2002.1154

Krashen, S. (1982). Principles and Practices in Second Language Acquisition. Oxford: Pergamon.

Krumhansl, C. (2000). Rhythm and Pitch in Music Cognition. Psychological Bulletin, 126(1), 159-179.

Kryszewska, H. (2010). Ideas from the Corpora: Word Clouds. Humanising Language Teaching Magazine for teachers and teacher trainers, 12(3). Retrieved 20.12.2012 from http://www.hltmag.co.uk/jun10/idea.htm

Lake, R. (2003). Enhancing Acquisition through Music. The Journal of Imagination in Language Learning, Jersey City State College, 7.

Lam, W., \& Wong, J. (2000). The effects of strategy training on developing discussion skills in an ESL classroom. ELT Journal, 54(3), 245-255. http://dx.doi.org/10.1093/elt/54.3.245

Leith, W. (1979). Advanced French Conversation through Popular Music. The French Review, 52(4), 537-551.

Lems, K. (1996). For a Song: Music across the ESL Curriculum. Paper presented at Annual Meeting of the Teachers of English to Speakers of Other Languages, 1-18. ED 396524.

Lems, K. (2001). Using Music in the Adult ESL Classroom (1-4). Paper presented at National-Louis University.

Levitin, D., \& Menon, V. (2003). Musical structure is processed "language" areas of the brain: a possible role for Brodmann Area 47 in temporal coherence. NeuroImage, 20, 2142-2152. http://dx.doi.org/10.1016/j.neuroimage.2003.08.016

Livingstone, F. (1973). Did the Australopithecines Sing? Current Anthropology 14(1, 2), 25-29. http://dx.doi.org/10.1086/201402

Locastro, V. (1994). Learning Strategies \& Learning Environments. TESOL Quarterly, 28(2), 409-414. http://dx.doi.org/10.2307/3587445

Lock, G. (2009). Next to Me. Tutortunes: Pop Songs with a Learning Element for ESL. Retrieved 20.12.2012 from http://tutortunes.net/tutortunes/category/samples

Loewy, J. (1995). The Musical Stages of Speech: A Developmental Model of Pre-verbal Sound Making. Music Therapy, 13(1), 47-73.

Lozanov, G. (1978). Suggestology and outlines of suggestopedy. New York: Gordon and Breach Publishing.

Maess, B., Koelsch, S., Gunter, T., \& Friederici, A. (2001). Musical syntax is processed Broca's area: an MEG study. Nature Neuroscience, 4(5), 540-545.

Magahay-Johnson, W. (1984). Music Hath Charms: Music and Student-Created Stories in the ESL Classroom. TESL Canada Journal/Revue TESL du Canada, 1(1), 81-82.

McGrath, I. (2002). Materials Evaluation and Design for Language Teaching. Edinburgh: Edinburgh University Press.

McMillan, D., \& Chavis, D. (1986). Sense of Community: A Definition and Theory. Journal of Community Psychology, 14(1), 6-23. http://dx.doi.org/10.1002/1520-6629(198601)14:1<6::AID-JCOP2290140103>3.0.CO;2-I

McMullen, E., \& Saffran, J. (2004). Music and Language: A Developmental Comparison. Music Perception, 21(3), 289-311. http://dx.doi.org/10.1525/mp.2004.21.3.289

Medina, S. (1990). The effects of music upon second language vocabulary acquisition. Paper presented at the 
TESOL conference. San Francisco, CA. ED352834.

Merriam, A. (1964). The Anthropology of Music. Evanston: Northwestern University Press.

Mishan, F. (2005). Designing Authenticity into Language Learning Materials. Bristol: Intellect Books.

Mol, H. (2008). Days of the Week. Supasongs: Learning English Through Music. Retrieved 20.12.2012 from https://secure.ntechmedia.com/sites/supasongs/index.php?template=Main\&catid=1

Murphey, T., \& Alber, J. (1985). A Pop Song Register: The Motherese of Adolescents as Affective Foreigner Talk. TESOL Quarterly, 19(4), 793-795. http://dx.doi.org/10.2307/3586679

Murphey, T. (1989). The Top 40 for Teachers (in no special order). The Language Teacher XIII(5), 3-6.

Murphey, T. (1990). The Song Stuck in My Head Phenomenon: A Melodic Din in the LAD? System, 18(1), 53-64. http://dx.doi.org/10.1016/0346-251X(90)90028-4

Murphey, T. (1992a). Music and Song. Oxford: Oxford University Press.

Murphey, T. (1992b). The Discourse of Pop Songs. TESOL Quarterly, 26(4), 770-774. http://dx.doi.org/10.2307/3586887

Murphey, T. (2010). Personal communication with the author.

Nagy, W., \& Herman, P. (1987). Breadth and Depth of Vocabulary Knowledge: Implications for Acquisition and Instruction. In McKeown, M., \& M. Curtiss (eds.), The Nature of Vocabulary Acquisition (pp. 19-35). Hillsdale: Erlbaum Publishers.

Naiman, N., Frohlich, M., Stern, H., \& Todesco, A. (1996). The Good Language Learner. Clevedon, UK: Multilingual Matters.

Nantais, K., \& Schellenberg, E. (1999). The Mozart Effect: An Artifact of Preference. Psychological Science, 10(4), 370-373. http://dx.doi.org/10.1111/1467-9280.00170

Ndububa, K., \& Ajibade, Y. (2006). Effects of Word Games, Culturally Relevant Songs and Stories on Students' Motivation in a Nigerian English Language Class. European Journal of Social Sciences, 2(2), 240-250.

Nguyen, P., Terlouw, C., \& Pilot, A. (2006). Culturally appropriate pedagogy: the case of group learning in a Confucian Heritage Culture context. Intercultural Education, 17(1), 1-19. http://dx.doi.org/10.1080/14675980500502172

Nunan, D. (1989). Designing tasks for the Communicative Classroom. Cambridge: Cambridge University Press.

Nunan, D. (2004). Task-Based Language Teaching. Cambridge: Cambridge University Press.

Odlin, T. (1986). Another Look at Passage Correction Tests. TESOL Quarterly, 20(1), 123-130. http://dx.doi.org/10.2307/3586394

Orlova, N. (2003). Helping Prospective EFL Teachers Learn How to Use Songs in Teaching Conversation Classes. The Internet TESL Journal, IX(3). Retrieved 20.12.2012 from http://iteslj.org/Techniques/Orlova-Songs.html

Oxford, R. (1990). Language Learning Strategies: What Every Teacher Should Know. Boston, Heinle and Heinle.

Palmer, P. (1998). The Courage to Teach: Exploring the Inner Landscape of a Teacher's Life (2 ${ }^{\text {nd }}$ edition). (2007). San Francisco: Jossey-Bass.

Palmer, C., \& Kelly, M. (1992). Linguistic Prosody and Musical Meter in Song. Journal of Memory and Language, 31, 525-542. http://dx.doi.org/10.1016/0749-596X(92)90027-U

Papousek, M., \& Papousek, H. (1981). Musical elements in the infant's vocalisation: their significance for communication, cognition, and creativity. In Lipsitt, L. (ed.), Advances in infancy research: Volume 1 (pp. 163-224). Norwood, Ablex Publishing Corporation.

Papousek, M., \& Papousek, H. (1991). Early Verbalizations as Precursors of Language Development. In Lamb, M., \& H. Keller (eds.), Infant Development: Perspectives from German-Speaking Countries (pp. 299-328). Hillsdale, Lawrence Erlbaum Associates, Inc. Publishers.

Patel, A., Edward, G., Ratner, J., Besson, M., \& Holcomb, P. (1998). Processing Syntactic Relations in Language and Music: An Event-Related Potential Study. Journal of Cognitive Neuroscience, 10(6), 717-733. http://dx.doi.org/10.1162/089892998563121 
Patel, A. (2003). Language, music, syntax and the brain. Nature Neuroscience, 6(7), 674-681. http://dx.doi.org/10.1038/nn1082

Paterson, A., \& Willis, J. (2008). English Through Music. Oxford: Oxford University Press.

Pennycook, A. (2003). Global Englishes, Rip Slyme, and performativity. Journal of Sociolinguistics, 7(4), 513-533. http://dx.doi.org/10.1111/j.1467-9841.2003.00240.x

Pennycook, A. (2007). Global Englishes and Transcultural Flows. New York: Routledge.

Peretz, I. (2002). Brain Specialization for Music. The Neuroscientist, 372-380. http://dx.doi.org/10.1111/j.1749-6632.2001.tb05731.x

Plagwitz, T. (2006). Karaoke in the Digital Audio Lab. Proceedings of the Digital Stream Conference 2006 at California State University, Monterey Bay, ISSN 1946-1526.

Pope, R. (1995). Textual Intervention: Critical and Creative Strategies for Literary Studies. London: Routledge.

Rauscher, F., Shaw, G., \& Ky, K. (1993). Music and Spatial Task Performance. Nature, 365, 611. http://dx.doi.org/10.1038/365611a0

Rauscher, F., Shaw, G., \& Ky, K. (1995). Listening to Mozart enhances spatial-temporal reasoning: towards a $\begin{array}{llllll}\text { neurophysiological } & \text { basis. } & \text { Neuroscience } & \text { Letters, } & 185, & 44-47 .\end{array}$ http://dx.doi.org/10.1016/0304-3940(94)11221-4

Redding, J. (2006). Rock Talk by Request. Rock Talk: America's Number One Musical Phonics Program for ESL. Retrieved 20.12.2012 from www.eslrocks.com

Richards, J. (1969). Songs in Language Learning. TESOL Quarterly, 3(2), 161-174. http://dx.doi.org/10.2307/3586103

Richards, J., \& Rodgers, T. (2008). Approaches and Methods in Language Teaching. Cambridge: Cambridge University Press.

Rubin, D. (1995). Memory in Oral Traditions: the Cognitive Psychology of Epic, Ballads, and Counting-Out Rhymes. New York: Oxford University Press.

Salcedo, C. (2010). The Effects of Songs in the Foreign Language Classroom on Text Recall, Delayed Text Recall and Involuntary Mental Rehearsal. Paper presented at 2010 IABR (International Applied Business Research) \& ITLC (International College Teaching and Learning) Conference Proceedings, 1-12.

Saricoban, A., \& Metin, E. (2000). Songs, Verse and Games for Teaching Grammar. The Internet TESL Journal, $V I(10)$. Retrieved 20.12.2012 from http://iteslj.org/Techniques/Saricoban-Songs.html

Schoepp, K. (2001). Reasons for Using Songs in the ESL/EFL Classroom. The Internet TESL Journal, VII(2). Retrieved 20.12.2012 from http://iteslj.org/Articles/Schoepp-Songs.html

Schön, D., Boyer, M., Moreno, S., Besson, M., Peretz, I., \& Kolinsky, R. (2008). Songs as an aid for language acquisition. Cognition 106(2), 975-983. http://dx.doi.org/10.1016/j.cognition.2007.03.005

Schunk, H. (1999). The Effect of Singing Paired with Signing on Receptive Vocabulary Skills of Elementary ESL Students. Journal of Music Therapy, XXXVI(2), 110-124.

Shaw, A. (1970). How to make Songs for Language Drill. English Language Teaching, 24(1), 125-132. http://dx.doi.org/10.1093/elt/XXIV.2.125

Sinclair, B. (1996). Learner autonomy and literature teaching. In Carter, C., \& McRae, J. (eds.), Language, Literature and the Learner: Creative Classroom Practice (pp. 138-150). New York, Longman.

Skehan, P. (1998). A Cognitive Approach to Language Learning. Oxford, Oxford University Press.

Slevc, L., Rosenberg, J., \& Patel, A. (2008). Language, Music, and Modularity: Evidence for Shared Processing of Linguistic and Musical Syntax. Proceedings of the $10^{\text {th }}$ International Conference on Music Perception and Cognition ICMPC10), Japan, 598-605.

Smith, G. (2003). Music and mondegreens: extracting meaning from noise. ELT Journal, 57(2). 113-121. http://dx.doi.org/10.1093/elt/57.2.113

Steele, K., Bass, K., \& Crook, M. (1999). The Mystery of the Mozart Effect: Failure to Replicate. Psychological Science, 10(4), 366-369. http://dx.doi.org/10.1111/1467-9280.00169

Steele, K., Bella, S., Peretz, I., Dunlop, T., Dawe, L., Humphrey, G., Shannon, R., Kirby, J. Jr., \& Olmstead, C. 
(1999). Prelude or requiem for the 'Mozart effect'? Nature, 400, 827.

Steinke, W., Cuddy, L., \& Holden, R. (1997). Dissociation of Musical Tonality and Pitch Memory from Nonmusical Cognitive Abilities. Canadian Journal of Experimental Psychology, 51(4), 316-334. http://dx.doi.org/10.1037/1196-1961.51.4.316

Techmeier, M. (1969). Music in the Teaching of French. The Modern Language Journal, 53(2), 96. http://dx.doi.org/10.1111/j.1540-4781.1969.tb04568.x

Thompson, B., \& Andrews, S. (2000). An Historical Commentary on the Physiological Effects of Music: Tomatis, Mozart and Neuropsychology. Integrative Physiological and Behavioral Science, 35(3), 174-188. http://dx.doi.org/10.1007/BF02688778

Trainor, L., Austin, C., \& Desjardins, R. (2000). Is Infant-Directed Speech Prosody a Result of the Vocal Expression of Emotion? Psychological Science, 11(3), 188-195. http://dx.doi.org/10.1111/1467-9280.00240

Trehub, S., Trainor, L., \& Unyk. (1993). Music and Speech Processing in the First Year of Life. In Reese, H. (ed.), Advances in Child Development and Behavior (Volume 24) (pp. 2-29). London: Academic Press, Inc.

Trehub, S., \& Trainor, L. (1998). Singing to Infants: Lullabies and Play Songs. In Rovee-Collier, C., L. Lipsitt, $\&$ H. Hayne (eds.), Advances in Infancy Research (Volume 12) (pp. 43-78). Stamford: Alex Publishing Corporation.

Wellman, L., \& Byrd, D. (1975). Hard to Learn that English as a Second Language Blues. New York: Collier McMillan.

Wilcox, W. (1995). Music cues from classroom singing for second language acquisition: Prosodic memory for pronunciation of target vocabulary by adult non-native English speakers. Doctoral dissertation, University of Kansas: UMI 9544866.

Wong, P., \& Perrachione, T. (2007). Learning pitch patterns in lexical identification by native English-speaking adults. Applied Psycholinguistics, 27, 565-585. http://dx.doi.org/10.1017/S0142716407070312

Wray, A., \& Perkins, M. (2000). Functions of Formulaic Language. Language and Communication, 20, 1-28. http://dx.doi.org/10.1016/S0271-5309(99)00015-4

Zatorre, R., Meyer, E., Gjedde, A., \& Evans, A. (1996). PET Studies of Phonetic Processing of Speech: Review, Replication, and Reanalysis. Cerebral Cortex, 6, 21-30. http://dx.doi.org/10.1093/cercor/6.1.21 